\title{
The Role Natural Tafakur Activities in Improving The Faith of Student Islamic Boarding School Jagad 'Alimussirry
}

\author{
N L Magfiroh \\ Islamic Building School of Jagad Alimussirry Surabaya, Indonesia \\ Email: nurlailamaghfiroh524@gmail.com
}

\begin{abstract}
Tafakur is an activity of internal thinking that includes the processes and knowledge possessed by individuals in the cognitive aspect, involving feelings and emotions in the affective aspect, and specifically in this case the spiritual aspect. In the modern era, in increasing the faith of students, it does not have to be done with the activities of reciting the Islamic boarding school. The students' faith can be improved by learning or reciting the Qur'an in the wild. Learning in outside of Islamic boarding school can bring student integrated with nature. Nature will open the horizons of student's wider view. This method of learning with nature is expected to establish harmony between learning material inside Islamic boarding schools and outside Islamic boarding schools or that can be called natural meditation. The nature recitation activities to increase the students' faith carried out by Islamic Boarding School Jagad Alimussirry include material giving activities by presenters who are experts in their fields, nature exploring, obligatory prayers or sunnah in congregation, the cult of each group, and the night devotions.
\end{abstract}

Keywords:natural tafakur; faith; student of Jagad Alimussirry Islamic Boarding School

\section{INTRODUCTION}

Islamic boarding schools are the main pillars of religious education that arise and develop from the community, whose existence is directly felt by the community itself. Islamic boarding school educational institutions are believed to be able to increase the faith of students in the boarding school, and the community around the boarding school through study activities held by the boarding school. The history of the Indonesian people records that Islamic boarding school has played a large role in efforts to strengthen faith, increase devotion, and build noble character, so that many parents entrust their children to Islamic boarding schools in the hope that their children can deepen religious knowledge and to strengthen faith to Allah SWT.
Faith is a confession in the heart of the oneness of God and the truth of the apostles everything they bring from God. Speaking verbally and doing the pillars of Islam is a branch of faith.1 A person who believes seriously and is spoken with words and deeds, then that is actually a believer again Muslim. This is what is praised and desired by God, which is in accordance with his birth and mind.2 Believers who believe in His qada and qadar, are brave, not afraid. Because he was determined that there was no difficulty and ease, wealth or poverty, life and death, but with the provisions of God. The expression of faith of a believer is to carry out God's commands, both directly related to God and to humans (habl min Allah and habl min alnas).3

The wisdom contained in Surah Al-Anfal verse 64 is that it is sufficient for Allah for 
those who believe in Him and depend on Him, faith is the main foundation in achieving victory, the obligation to believe by loving God alone.

In the modern era, in increasing the faith of students, it does not have to be done with the activities of reciting the Islamic boarding school. The students' faith can be improved by learning or reciting the Qur'an in the wild. Learning in outside of Islamic boarding school can bring student integrated with nature. Nature will open the horizons of students view more broadly. This method of learning with nature is expected to establish harmony between learning material inside Islamic boarding schools and outside Islamic boarding schools or that can be called natural meditation. The students' curiosity about the universe not only reads the Qur'an, but also pays close attention to the signs of His power in the universe to inspire the mind and the heart to accept the truth.

Therefore, the activity of natural meditation is considered very important to be held in Islamic boarding school educational institutions. Etymologically, tafakur comes from the Arabic word, tafakkara, which means thinking. Thinking in question is an activity, which combines the physical or emotional, mental, and spiritual components of humans in contemplating a phenomenon and aims to find the phenomenon or answer in question. Thus ontologically, contemplation is more likely to mean contemplation rather than thinking. According to its depth, tafakur is different from ordinary thinking activities (tafkir) which only work on world problems that are not based on faith. A person who is contemplating then he will be able to pass the reality of the world to the hereafter, from creation to the Creator, which ultimately produces a valuable lesson.

From the statements above about the importance of natural tafakur for students, the authors are interested in writing a paper entitled "The Role Natural Tafakur Activities
In Improving The Faith of Student Islamic Boarding School Jagad 'Alimussirry”.

\section{METHOD}

This study uses a literature review to uncover ka $\mathrm{n}$ how Sufism on the problematic relation between education and life. Literatures used include books, articles, and trusted sites. By comparing various exposures from the literature, the author analyzes, identifies and reviews to produce a more objective view of the need for sufistic education to deal with the problems of the times.

\section{RESULT AND DISCUSSION}

\section{A. Tafakur alam according to Islamic psychology}

Tafakur is an internal thinking activity that includes the processes and knowledge possessed by individuals in the cognitive aspect, involving feelings and emotions in the affection aspect, and specifically in this case the spiritual aspect.5

The difference between tafakur and ordinary thinking activities (tafkir) is that tafakur is a thought process that is able to pass the reality of the world to the hereafter, by involving aspects of affection so as to cause special sensations in humans to their God and ultimately add more quality knowledge in terms of belief in God. Through contemplation, human beings are free from material confinement towards unlimited spiritual freedom, which then drives all individual knowledge activities. The individual will benefit from his past experiences, then with his perception all those experiences are associated with the creatures that are the object of his contemplation.

Through the discovery of God's verses in nature, an individual is said to have discovered wisdom (ibrah) and inspiration which is a kind of knowledge that is given by God to a person and is sent to his heart, so that some of his 
secrets are revealed and evident by some reality. 6 another, ordinary thinking activity (tafkir) is only limited to solving worldly problems, which are likely to be far from touching feelings and emotions.7

Tafakur includes four interrelated stages, namely:

\section{First stage}

Man begins with the knowledge he obtained through direct perception using sight, hearing, touch and the other five senses. Indirect way with imagination or pure intellectual activity.

\section{Second stage}

If humans try to observe the object of tafakur further by paying attention to its beauties, it means that he has moved from cold knowledge to the awe of the beauty and greatness of the creation. This stage is the time when humans feel the surge in the heart of $s$ heart.

\section{Third stage}

A stage in which the surge in the self that rises toward awareness and recognition of the attributes of the majesty of God This adds to the solemnity and people feel very close to their Lord.

\section{The fourth stage}

If the previous stages are often done and become deeply rooted habits. Everything that used to seem ordinary, now turns into a source of wealth in thinking, presents a sense of devout and contemplation of various favors of God. At this stage, everything in his environment has turned into a stimulus for him to always think and reflect. At this stage he also attains the opening of the door of witness to the majesty of God and the door of witness to the resurrection day. He sees creatures moving according to His commands and wills, submitting to Him. All that he witnessed will strengthen the sincerity of his heart in religion.

\section{B. Tafakur alam activities to increase faith in the Islamic Boarding School Jagad Alimussirry}

To increase faith in Islamic Boarding School Jagad 'Alimussirry, the student Executive Board (BES) Islamic Boarding School Jagad Alimussirry conducts a work program every year, namely the natural tafakur. Tafakur alam at this lodge is usually held outside the boarding school which is still natural place such as in the Pacet District or Malang Regency. This activity of nature recitation is recommended to temporarily eliminate the mundane thoughts to focus on later life, the afterlife through the creations of Allah SWT. The activities of nature contemplation carried out by Islamic Boarding School are as follows:

\section{Giving Material}

Provision of this material is usually given by presenters who have mastered their fields. Presenters were usually brought in from outside the Islamic boarding school as well as from the student and alumni of Islamic Boarding School Jagad Alimussirry. The theme in the presentation of this material is usually an agreement of the committee and the speaker, but still refers to the purpose of giving material that is to increase knowledge and improve the spirituality of students. The difference in the provision of material in nature and hut activities is the atmosphere, and the material taught is packaged in a pleasant form. A different and pleasant atmosphere will increase the spirit of students to capture spiritual material provided by the speaker.

\section{Explore the nature}

This nature exploration activity is the most important activity in a series of tafakur alam events. Because in this nature exploration activity students are invited directly to learn about God's creation in the universe. This nature roaming is usually formed posts, where each post there is a speaker. To go to the posts 
that have been formed, students travel through the foot of mountains, forests, rivers, rice fields, and so forth. At this stage the student sees with the knowledge he obtained through direct perception using sight, hearing, touch and other senses. Indirect way with imagination or pure intellectual activity. Then after that students will try to observe the object that they see so by paying attention to its beauties, it means that he has moved from the knowledge they have gained to the submission of the beauty and greatness of the creation. This stage is the time when the students feel the surge in the heart that shakes, after that the surge in this self will increase towards awareness and recognition of the majesty of Allah SWT. This will add solemnness and students will feel close to Allah SWT. If these stages are often carried out and become a habit that is rooted in themselves. Everything that seems ordinary, is now a source of wealth in thinking, presenting a sense of solemnity, and contemplation of various favors of Allah SWT. At this stage everything in his environment has turned into a stimulus for him to always think and reflect.

Then after a long journey of prayer at the same time students will go to the posts where in the post are also a lot of material about tafakur for example eyes are closed like a blind man then told to walk looking for something or walk towards the expected destination, here students will feel a sense of being very grateful to God SWT has given five senses that are still good. The activity in the next post is the post of death, here the students are given contemplation about the bodies who died in a state of special khusnul khotimah and su'ul khotimah through contemplation of the two bodies before the students will realize that life in this world is only temporary because it must obey the commands of Allah and stay away from His prohibition. In this post, at once taught how to care for the body. Then the activities in the next posts are the contemplation of the Qur'anic verses on the journey to the next post, listening to the sound of water, and so on whose purpose is to increase the students' faith.

\section{Dhuha and tahajud prayer in congregation}

Dhuha and tahajud prayer in congregation are part of nature's recitation activities, where this activity can draw closer to Allah SWT, and it is recommended to carry out these two worship services so that it becomes a habit, both during natural recitation activities and after returning from this activity, because there are so many benefits that can be taken from both these sunnah prayers and other sunnah prayers.

\section{Cult}

This cult activity can increase knowledge and increase the students' faith because here the students will learn how to prepare the culture material, and listen to the cult from other group friends.

\section{Night Meditations}

This evening devotional activity is usually carried out when the last night is on natural recitation activities. Tonight's reflection is guided by someone who is an expert in his field so that in the reflections tonight the students will be reminded of the sins that have been committed, in this activity students will feel they have a lot of sins and as much as possible to ask forgiveness from Allah SWT and also to the people that they behaved badly. It is hoped that after this reflection the students will always be accustomed to contemplate all the sins they have committed, are always kind to their fellow humans, and do not forget to always ask for forgiveness from Allah the creator of the universe.

\section{CONCLUSION}

The difference between tafakur and ordinary thinking activities (tafkir) is that tafakur is a thought process that is able to pass the reality of the world to the hereafter, by involving aspects of affection so as to cause special sensations in humans to their God and 
ultimately add more quality knowledge in terms of belief in God. Through contemplation, humans are free from material confinement towards unlimited spiritual freedom, which then drives all individual knowledge activities. The individual will benefit from his past experiences, then with his perception all those experiences are associated with the creatures that are the object of his contemplation.

\section{REFERENCES}

[1] M. Badri, 2001, Fiqh Tafakur: Dari Perenungan Menuju Kesadaran.Surakarta : Era Intermedia.

[2] U. Munandar, 2002, Menjadi Manusia Kreatif Melalui Tafakur, Makalah tidak diterbitkan.

[3] T. Mu'in, 1986, Ilmu Kalam, Jakarta: Widya.

[4] G Munir, 2008, Ilmu Kalam: Pemikiran dan Kehidupan, Semarang: Rasail Media Group.

[5] F. Nashori, 2002, Beberapa Jalan Meneteskan Ide-Ide Kreatif, Makalah tidak diterbitkan.

[6] E. Prahara, 2009, Menteri Pendidikan Agama Islam, Ponorogo: STAIN Ponorogo. 